関西地域の住宅における冬期の実態調查による中立温度・許容範囲の算出

\title{
CALCULATION OF NEUTRAL TEMPERATURE AND ACCEPTABLE RANGE BY THE FIELD STUDY OF HOUSES IN KANSAI AREA, JAPAN, IN WINTER
}

\author{
飛田国 人*1，中谷岳史*2，松原 斎 樹*3，藏澄 美仁*4，島田理 良*2 \\ Kunihito TOBITA, Takashi NAKAYA, Naoki MATSUBARA, \\ Yoshihito KURAZUMI and Riryo SHIMADA
}

\begin{abstract}
Thermal environment of the houses in Kansai area, Japan, was investigated in winter. This paper discussed indoor climate and thermal comfort.

The main results are as follows; 1) the ratio of occupants who did warming action such as to use kotatsu or electric carpet, as well as using heating such as air-conditioning and heaters was higher than that of occupants who used heating only, 2) the neutral temperature was $9.9^{\circ} \mathrm{C}\left(\mathrm{ET}^{*}\right)$ when occupants didn't do warming action, 3) the neutral temperature was $9.9^{\circ} \mathrm{C}(\mathrm{Tg}), 10.9^{\circ} \mathrm{C}$ (OT), $10.9^{\circ} \mathrm{C}\left(\mathrm{ET}^{*}\right)$ when occupants wore much clothing, 4) more than $90 \%$ of occupants responded "acceptable", despite $70 \%$ of the temperature data varying from ASHRAE Standard55.
\end{abstract}

Keywords: field study, thermal comfort, house, winter, neutral temperature, acceptable range 実態調查, 熱的快適性, 住宅, 冬期, 中立温度, 許容範囲

\section{1.はじめに}

温暖化対策は政府や企業だけでなく, 一般家庭にも求められてい る。政府は夏期と冬期の空調に費やされるエネルギーが膨大である ことから, 住宅・ビル等の室温を冷房中は $28^{\circ} \mathrm{C}$ 以上 ${ }^{1)}$, 暖房中は $20^{\circ} \mathrm{C}$

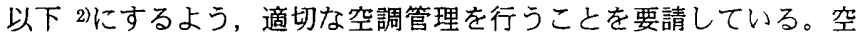
調管理では, ISO77303)や空調オフィス環境の基準であるASHRAE Standard4)などの, 実験室実験をもとに定められた許容範囲などが 用いられている。しかし, 実態調查の方が実験室実験よりも居住者 はより広い温度の幅を許容する5)ことが報告されており，この差異 の原因の 1 つに居住者の適応行動がある6)。

国内でも温熱環境の調査に関する報告は多く，オフィスよりも住 宅の方が自由意志で環境をコントロールできる立場にあり 7，住宅 の居住者が断熱性能の差異によってさまざまな生活行為を行ってい ることが明らかにされている 8)。そのような中で, 住宅とビルに同 じ基準を設け, 実験室実験をもとに定められた海外の空調オフィス の基準を日本の住宅に用いることの是非を検討するためには，実態 を調査してさまざまな検討を行う必要がある。しかし，中立温度・ 許容範囲を扱った日本の住宅での実態調查は少ない。中谷ら9)注関 西地域の住宅の夏期の中立温度は $28.6^{\circ} \mathrm{C}\left(\mathrm{ET}^{*}\right)$, 許容範囲の上限は $28.0^{\circ} \mathrm{C}(\mathrm{OT})$ であったことを報告しているが, 冬期の中立温度と許容
範囲については明らかにされていない。そこで本研究では関西地域 の住宅を対象として, 冬期の中立温度と許容範囲を求めることを試 み，その結果について考察することを目的とする。

\section{2. 調查概要}

調査対象地域は兵庫県宝塚市および大阪府高槻市である。住戸種 類は戸建住宅 21 戸および集合住宅 20 戸の計 41 戸である。調査人 数は 47 人で男性 3 人, 女性 44 人である。調查期間は 2004 年 2 月 3 日〜 3 月 6 日である。

調査内容は, (1)室内の温熱環境, (2)温熱環境に対する主観申告, (3)生活時間の 3 種類であった。調查訪問時に, (1)の測定機器を設置 するとともに，居住者に調査内容の説明をした。二日間の調查期間 中は，居住者に(2)(3)の記入を依頼した。

調査日数は各住戸 4 日間である。各住戸には事前に連絡をして調 査の承諾を得てから訪問を行った。調查初日は, 再度調查協力の確 認を行い, 趣旨の説明, 室内への調査器具設置の承諾, 調査器具の 説明, 調查器具の設置, 主観申告·生活時間調查用紙の説明を行い, 被験者から質問がないか最後に尋ねた。また測定期間中は普段通り に生活するように教示を与えた。2 日目と 3 日目に，被験者は主観 申告及び生活時間調査用紙に記入を行い，測定器具で環境デー夕を

\footnotetext{
*1 有明工業高等専門学校建築学科 助手

$* 2$ 大和八门ス工業姝

*3 京都府立大学人間環境学部環境デザイン学科＼cjkstart教授・工博

*4 広島国際大学工学部住環境デザイン学科 教授・工博
}

Research Assoc., Dept. of Architecture, Ariake National College of Technology Daiwa House Industry Co., Ltd.

Prof.. Dept. of Environmental Design, Kyoto Pref. Univ., Dr. Eng.

Prof., Dept. of Socio-Environment Design, Faculty of Engineering, Hiroshima International Univ., Dr. Eng. 
表 1 代謝量および主観申告尺度

\begin{tabular}{|c|c|}
\hline 調查項目 & カテデリ \\
\hline 代謝量 & 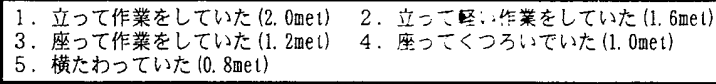 \\
\hline 温冷感 & 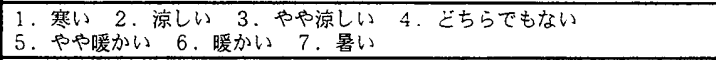 \\
\hline 許容感 & 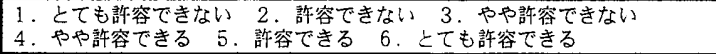 \\
\hline 熱的 & 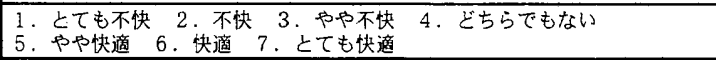 \\
\hline
\end{tabular}

表 2 主観申告時の暖房行為之採暖行為

\begin{tabular}{c|c|c}
\hline 項 & 申告数 & 割合 $(\%)$ \\
\hline 暖房 +採暖行為 & 151 & 38.1 \\
\hline 暖房行為のみ & 133 & 33.6 \\
\hline 採暖行為のみ & 41 & 10.4 \\
\hline 行為無 & 71 & 17.9 \\
\hline 合計 (全申告) & 396 & 100 \\
\hline
\end{tabular}

自動記録した。4 日目に用紙及び測定器具の回収を行い，用紙の 記入に不備があれば口頭で補足した。調査終了後に, 相当分の謝 礼を全被験者に手渡した。室内の温熱睘境の測定項目は, 環境側 4 条件(空気温度 $\mathrm{Ta} \cdot$ グローブ温度 $\mathrm{Tg}$ ・湿度 $\mathrm{RH}$ ・風速 $\mathrm{v}$ ) と人体 側 2 条件(代謝量 $\mathrm{M}$ ・着衣量 $\mathrm{Icl}$ )である。環境側条件の測定は，グ ローブ温度計 $(\phi=150 \mathrm{~mm})$, 携帯型データロガー(エスペック社 製 RS-11，RT-11），熱線風速計(KANOMAX 社製，Model6021)を用 いた。測定点は, 気温: 床上 $0.1 \mathrm{~m}, 0.7 \mathrm{~m}, 1.1 \mathrm{~m}$, 湿度, 気流速: 床 上 $1.1 \mathrm{~m}$, 黑球温度計:床上 $0.7 \mathrm{~m}$ とした。測定間隔は 5 分である。 人体側条件のうち, 着衣量は調查期間中の日中・夜間·就寝時の着衣 を記入させた。代謝量は主観申告回答時に記入させた。代謝量は主 観申告の際に 5 段階の作業強度 $(0.8 \sim 2.0 \mathrm{met})$ を記入させることで 推定した 4)(表 1)。主観申告は，居住者自身に記入させた。測定した データをもとに, 温熱指標である作用温度, 新有効温度, 標準新有 効温度(以後, $\mathrm{OT}, \mathrm{ET}^{*}, \mathrm{SET}^{*}$ )を求めた。

主観申告は，温冷感，熱的許容度，熱的快適感を用いた(表 1)。温 冷感申告は, ASHRAEの 7 段階の温冷感尺度の日本語訳を用いた。 熱的許容度は，6段階の両極尺度であり，環境に対する感じ方を尋 ねる申告である。熱的快適感は，7段階の両極尺度を用いた。申告 をするにあたり, 温冷感, 熱的快適感は回答者自身の身体の感じ方 を, 熱的許容度は室内の熱環境を受け入れられるかを評価するよう に教示を与えた 10)。被験者には事前に，申告時の部屋の熱環境を評 価するよう依頼した。主観申告は(1)午前 8 時から午後 12 時まで 2 時間每の指定申告，(2)一日中かつ時間指定なしの自由申告，および (3)暖房器具や採暖器具の on/off を変更した際の申告とした。また「工 アコン使用開始直後」「帰宅直後」「入室直後」「入浴直後」などの状 況にあてはまるかを, 申告の際に記入させた。エアコンの使用開始 による室温の急激な上昇状態や，帰宅直後や入浴後の体温が上昇? た状態の申告は,「室滞在者の許容範囲の算出」に適さないと判断さ て分析から除外した。

生活時間調查注”に用いた調査用紙は, 横軸に時間軸, 縦軸に行為 軸を 10 分単位で記入させた。調査対象とふる居住者行動は, 生活 必需時間「睡眠, 食事, 身の回りの用事!汇加元, 暖房器具・採湲 器具の使用時間, 空開閉時間である。
表 3 温熱環境の調査結果

\begin{tabular}{c|r|r|r|r}
\hline 項 & 平均 & 標準偏差最小値 & 最大値 \\
\hline $\mathrm{Ta}\left[{ }^{\circ} \mathrm{C}\right]$ & 17.4 & 3.5 & 5.9 & 26.8 \\
\hline $\mathrm{RH}[\%]$ & 51.7 & 9.7 & 27.7 & 82.0 \\
\hline $\mathrm{AH}[\mathrm{g} / \mathrm{kg}]$ & 6.5 & 1.7 & 2.7 & 11.9 \\
\hline $\mathrm{Tg}\left[{ }^{\circ} \mathrm{C}\right]$ & 16.5 & 3.3 & 6.8 & 26.7 \\
\hline $\mathrm{Tfl}\left[{ }^{\circ} \mathrm{C}\right]$ & 14.7 & 3.1 & 5.6 & 22.3 \\
\hline $\mathrm{Ta}-\mathrm{Tfl}\left[{ }^{\circ} \mathrm{C}\right]$ & 3.0 & 2.2 & -3.2 & 9.5 \\
\hline $\mathrm{Tr}\left[{ }^{\circ} \mathrm{C}\right]$ & 16.5 & 3.3 & 6.8 & 26.7 \\
\hline $\mathrm{OT}\left[{ }^{\circ} \mathrm{C}\right]$ & 16.9 & 3.3 & 6.4 & 25.2 \\
\hline $\mathrm{ET} *\left[{ }^{\circ} \mathrm{C}\right]$ & 16.9 & 3.3 & 6.3 & 25.1 \\
\hline $\mathrm{SET} *\left[{ }^{\circ} \mathrm{C}\right]$ & 19.3 & 3.5 & 7.2 & 29.5 \\
\hline 代謝率 $[\mathrm{met}]$ & 1.3 & 0.4 & 0.8 & 2.0 \\
\hline 着衣量 $[\mathrm{clo}]$ & 0.79 & 0.2 & 0.42 & 1.11 \\
\hline
\end{tabular}
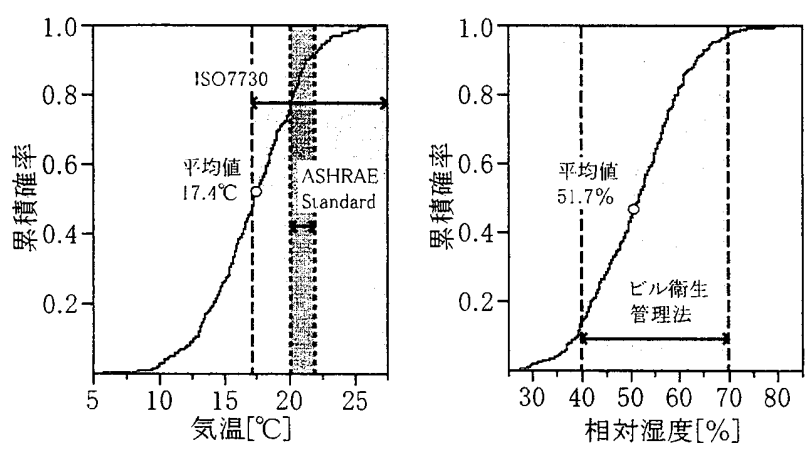

図 1 温度と相対湿度の累積確率

\section{3. 調查結果}

\section{1 暖房 $\cdot$ 採暖行為}

全温冷感申告の 暖房行為と採暖行為注 2)（ホットカーペット，こ たつ 11) 12), 暖房器具の採暖的使用 13)14)注3), カイロ 15), ひざ掛け) の割合を表 2 に示す。全温冷感申告 $(\mathrm{N}=396)$ のうち暖房, 採暖行為 ともに行っていない申告は全体の $17.9 \%(\mathrm{~N}=71)$, 暖房行為のうち工 アコン使用は $20.2 \%(\mathrm{~N}=80)$, 石油・ガスストーブなどエアコン以外 での暖房行為は $44.2 \%(\mathrm{~N}=175)$ であった。採暖行為のうちホットカ 一ペット使用は $27.3 \%(\mathrm{~N}=108)$, 暖房器具の採暖的使用は $20.2 \%$ $(\mathrm{N}=80)$ ，こたつ使用は $3.5 \%(\mathrm{~N}=14)$ ，力イロ使用は $2.3 \%(\mathrm{~N}=9)$, ひ ざ掛け使用は $2.0 \%(\mathrm{~N}=8)$ であった。また，暖房行為と採暖行為を同 時に行っていた申告の比率は全申告の $38.1 \%(\mathrm{~N}=151)$ であり, 暖房 行為のみの $33.6 \%(\mathrm{~N}=133)$ を回っていた。多くの居住者が暖房の みでは寒さをしのぎ切れず，補助的に採暖行為を行っていたと推測 される。

\section{2 温熱環境}

主観申告回答時の室内の温熱環境の調査結果を表 3 示す。また図 1 に気温と相対湿度の累積確率を示す。気温 Ta(FL.1.1m)デー夕の $45 \%$ がビル衛生管理法 16)の基準(気温 $17^{\circ} \mathrm{C}$ 以上)から， $70 \%$ が ASHRAE Standard ${ }^{4)}$ の快適域 $\left.\left(20 \sim 23.9^{\circ} \mathrm{C}\right) 17\right)$ から外れた低温な環

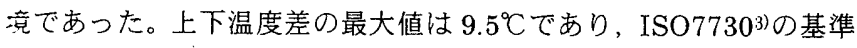
(3゚)外であった。相対湿度ではデータの $80 \%$ 年ル衛生管理法 16) つ基準(湿度 $40 \sim 70 \%$ )を満たし，また絶対湿度は $2.7 \sim 11.9 \mathrm{~g} / \mathrm{kg}$ 'の 望囲内であったので，ASHRAE が定める基準(12.0g/kg'以下) 4)を 满たした。風速は測定器の制約により全住戸の測定はできなかった $\therefore \therefore 14$ 件の測定データの平均值を解析に用いた。測定結果は 0 $0.19 \mathrm{~m} / \mathrm{s}$ の範囲で変動し, 平均值は $0.09 \mathrm{~m} / \mathrm{s}$ であった。放射温度(以 浲 Tr)の算出には(1)式 18)を用いた。 

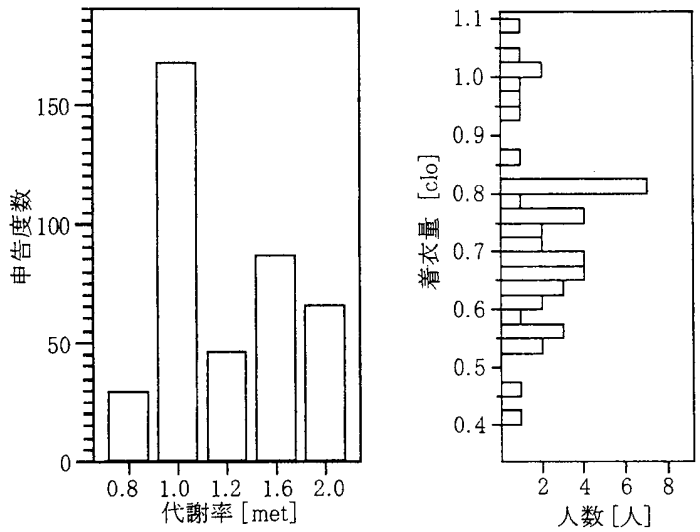

図 2 代謝率および着衣量の分布

表 4 各種温熱感覚の申告結果

\begin{tabular}{c|r|r|r|r|r}
\hline 項 & 平均標隻偏差最小值 & 最大值 & $\mathrm{N}$ \\
\hline 温冷感 & 5.2 & 1.2 & 1.0 & 7.0 & 396 \\
\hline 乾湿感 & 3.8 & 0.6 & 2.0 & 6.0 & 391 \\
\hline 熱的許容度 & 4.7 & 0.6 & 2.0 & 6.0 & 390 \\
\hline 湿度許容度 & 4.6 & 0.6 & 2.0 & 6.0 & 391 \\
\hline 熱的快適感 & 5.2 & 0.9 & 2.0 & 7.0 & 391 \\
\hline
\end{tabular}

$$
\operatorname{Tr}=\left[\frac{6.32 \cdot d^{-0.4} \cdot v^{0.5}}{\sigma \varepsilon}(\mathrm{Tg}-\mathrm{Ta})+\mathrm{Tg}^{4}\right]^{0.25} \quad\left[{ }^{\circ} \mathrm{C}\right] \quad \cdots \cdot(1)
$$

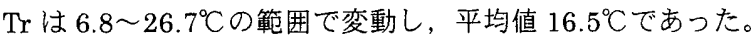

測定期間中の各温熱指標を算定した。OTは $6.4 \sim 25.2^{\circ} \mathrm{C}$ 範囲で 変動し, 平均值 $16.9^{\circ} \mathrm{C}$ であった。 $\mathrm{ET}^{*}$ は $6.3 \sim 25.1^{\circ} \mathrm{C}$ 範囲で変動 し, 平均值 $16.9^{\circ} \mathrm{C}$ であった。 $\mathrm{SET}^{*}$ は $7.2 \sim 29.5^{\circ} \mathrm{C}$ の範囲で変動し, 平均值 $19.3^{\circ} \mathrm{C}$ であった。

代謝率の作業強度は ASHRAE Standard4)から引用しており，「座 って作業をしていた」「座ってくつろいでいた」の「座る(seated)」 という表現は椅座を示している。日本では椅座, 床座の混在した生 活が行われており，椅座と床座では代謝率も異なる 1920)が，本調査 では椅座と床座を便宜的に同じ代謝率として推定した。申告された 代謝率の分布を図 2 に示す。代謝率は平均 $1.3 \mathrm{met}$ であった。これ は室内の軽い作業に相当する作業強度である。着衣量の推定は，日

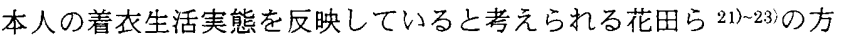
法を用いた。着衣量の分布を図 2 に示す。着衣量は $0.42 \sim 1.11$ (平均 0.79)cloであった。代表的な着衣例は, トレーナー, 長袖シャツ, ジーンズ，下着といった組み合わせであった。

\section{3 温熱感賞}

温熱感覚の申告結果を表 4 に, 分布を図 3 に示す。温冷感は平均 值 5.2 であり，「どちらでもない(4)」〜「暖かい(6)」に申告ボ分布 している。熱的許容度は平均值 4.7 であり，「やや許容できる(4) 〜「許容できる(5)」に申告の多くが分布していた。乾湿感は亚均值 3.8 であり，「やや乾燥している(3)」〜「どちらでもない(4)」に申 告が分布している。湿度の許容度は平均値 4.6 であり,「やや訐容て きる(4)」〜「許容できる(5)」に申告の大部分が分布していた，熱的 快適感は平均值 5.2 であり，「やや快適(5)」〜「快適(6)」に法す 大部分が分布していた。

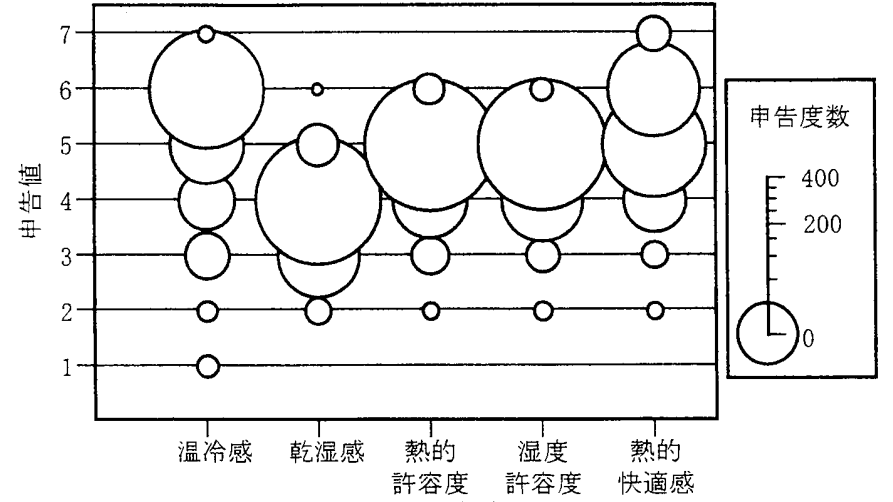

図 3 各種温熱感覚の申告分布

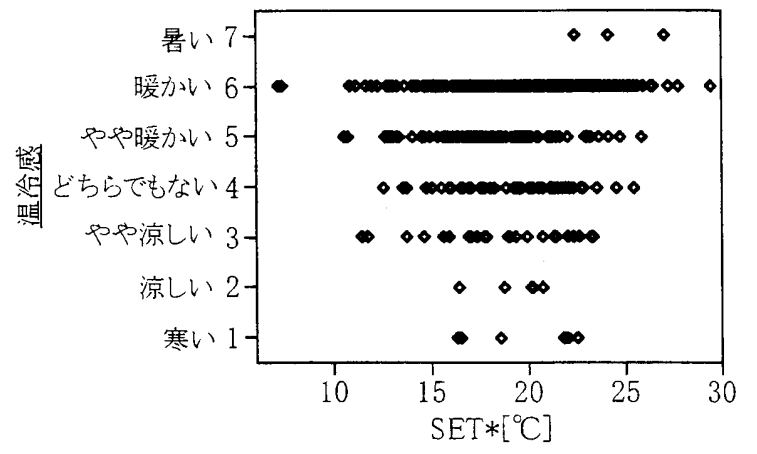

図 4 温冷感と $\mathrm{SET}^{*}$ の関係

\section{4. 考察}

\section{1 温冷感と SET*の関係}

温冷感との SET*との関係を図 4 に示す。SET*は 7.2〜29.5 ${ }^{\circ} \mathrm{C}$ の 範囲で変動し, 平均值は $19.3^{\circ} \mathrm{C}$ である。温冷感の申告総数は $\mathrm{N}=396$, 「やや暖かい(5)」が $\mathrm{N}=88(22.2 \%)$ 「暖かい(6)」が $\mathrm{N}=214(54.0 \%)$ となり, 冬期の調査にも関わらず「暑い」側の申告が多くみられる。 「やや暖かい(5)」「暖かい(6)」と申告されたときの温度範囲も広い。 また，「どちらでもない(4)」と申告されたときの温度範囲は 12.7 $25.6^{\circ} \mathrm{C}(0.4 \sim 1.1 \mathrm{clo})$ となり, ASHRAE が示している冬期の快適域 $\left(20 \sim 23.9^{\circ} \mathrm{C}\left(\mathrm{SET}^{*}\right)\right) 17$ 仍ら低い側にかなり広い。井関ら 24)は温冷感 申告に 9 段階の申告法を用いて分析を行い，休息時の温冷感申告で は「暖かい(3)」の申告が多くみられ，「どちらともいえない(5)」と 申告された温度も $12 \sim 20^{\circ} \mathrm{C}(\mathrm{Tg})$ と範囲がかなり広いことを報告し ている。本調査の結果も同様の傾向がみられた。

\section{2 中立温度}

中立温度とは, 温冷感尺度の「どちらでもない(4)」に相当する温 度である。中立温度は目的変数に温冷感尺度を用い, 説明変数を $\mathrm{ET}^{*}$ として，重み付け線形回帰分析により求めた。

説明変数として過去の研究に用いられてきたものには，PMV， $\mathrm{OT}, \mathrm{ET}^{*}, \mathrm{SET}^{*}, \mathrm{Ta}, \mathrm{Tg}, \mathrm{To}$ (外気温度)の 7 種類がある。今回調 査した住宅は ASHRAE Standardの快適域よりもかなり低温であ り，ビル管理法の温度基準も $45 \%$ が満たさない低温環境であった。 極端な暑熱・寒冷環境への PMV の適用は不適切とされる25ため, 本調査では PMVを用いないこととした。また，図 5 に Ta を説明 変数とした $\mathrm{Tg}, \mathrm{Tr}, \mathrm{OT}$ の単回帰分析の結果を示す。 3 つの回帰式 


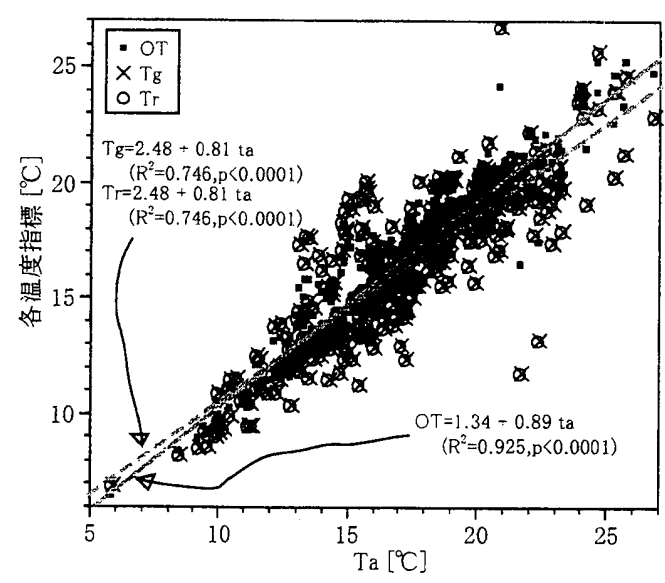

図 $5 \mathrm{Ta}$ と $\mathrm{Tg}, \mathrm{Tr}, \mathrm{O}$ と との関係

表 5 各種温度と温冷感との相関(採暖の有無による分類)

\begin{tabular}{c|c|c}
\hline & 採暖あり & 採暖なし \\
\hline $\mathrm{Ta}$ & $0.673 * *$ & $0.743 * *$ \\
\hline $\mathrm{Tg}$ & $0.424 *$ & $0.571 * *$ \\
\hline $\mathrm{OT}$ & $0.548 * *$ & $0.757 * *$ \\
\hline $\mathrm{ET}^{*}$ & $0.556 * *$ & $0.792 * *$ \\
\hline $\mathrm{SET}^{*}$ & $0.339+$ & $0.412 *$ \\
\hline \multicolumn{2}{|c}{$* *: \mathrm{p}<0.01, \quad *: \mathrm{p}<0.05, \quad+: \mathrm{p}<0.1$}
\end{tabular}

は近似しており， $\mathrm{Tg}$ のみで十分な可能性もある。しかし，冬期の 冷放射により $\mathrm{Tg}$ が気温よりも低い場合, $\mathrm{Tg}$ と人間の体感との対応 には注意する必要があり 26 ，本調查の結果だけでは $\mathrm{Tg}$ のみで十分 であるとは断言できない。

目的変数となる温冷感忙体感温度に関倸する。体感温度は採暖の 有無によって異なるため, 本研究では主観申告回答時に採暖行為を 行っているかどうかを調查し, 申告を(1)採暖行為時主観申告, (以降, 採暖あり)，(2)非採暖行為時主観申告(以降，採暖なし)に分類して考 察を行った。「採暖あり」時の申告は表 2 の「暖房十採暖行為」「採 暖行為のみ」の申告であり，「採暖なし」時の申告は表 2 の「暖房 行為のみ」「行為無」の申告である。

また, 居住者の環境調節行動の 1 つとして, 着衣量の調節がある。 着衣量の大小によっても体感温度は異なるため, 着衣量の四分位点 で居住者を(1)着衣量の多い(0.81〜 1.11clo)居住者 $25 \%$ (以降, 厚着の 居住者), (2)中程度の着衣量(0.63 0.81clo)の居住者 $50 \%$ (以降, 中 程度の居住者), (3)着衣量の少ない $(0.42 \sim 0.63 \mathrm{clo}$ )居住者 $25 \%$ (以降, 薄着の居住者)に分類して考察を行った。

\section{2.1 中立温度 (採暖の有無で申告を分類した場合)}

温度 $\left(\mathrm{Ta}, \mathrm{Tg}, \mathrm{OT}, \mathrm{ET}^{*}, \mathrm{SET}^{*}\right)$ と温冷感の相関を調べた結果(表 5), それぞれ正の相関（ピアソンの相関倸数 $\mathrm{r}=0.339 \sim 0.792$ )が観察 された。しかし， SET*と温冷感の相関倸数は他の值に比べて小さ いので $(\mathrm{r}=0.339,0.412)$, 説明変数として用いるのは不適当と判断 した。SET*は湿度, 風速, 代謝率, 着衣量を統制した標準環境に おける值を示す温度指標であるため, 各居住者の体感温度を同一条 件下で比較できる。ゆえに, 温熱感覚に全く個人差がなければ, 各 居住者は同じ体感温度 $\left(\mathrm{SET}^{*}\right)$ で同じ温冷感を申告し，今回用いた温 度の中では SET*がもっとも温泠感との相関が高くなるはずである。 しかし，そうならなかった理由について，一つの推論を試みる。

各居住者の温熱感覚の個人差が大きく，好みの体感温度が異なる

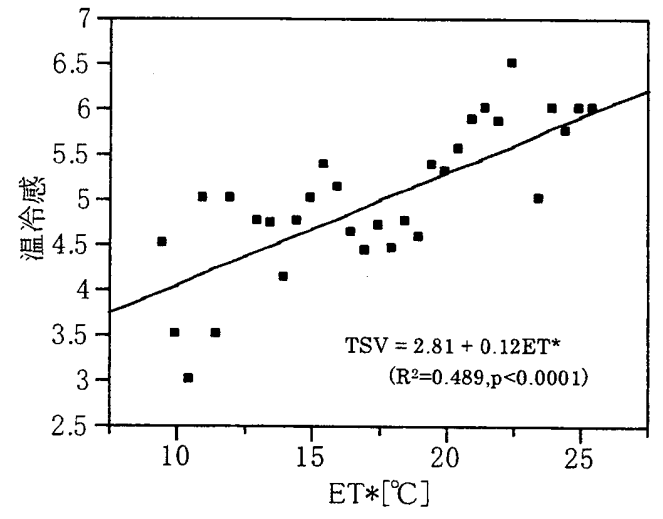

図 6 平均温冷感申告値と $\mathrm{ET}^{*}$ の関倸(採暖なし時)

表 6 各種温度と温冷感との相関(着衣量による分類)

\begin{tabular}{c|c|c|c}
\hline & 薄着 & 中程度 & 厚着 \\
\hline $\mathrm{Ta}$ & 0.167 & $0.552 * *$ & $0.752 * *$ \\
\hline $\mathrm{Tg}$ & -0.139 & $0.502 * *$ & $0.736 * *$ \\
\hline $\mathrm{OT}$ & -0.017 & $0.508 * *$ & $0.720 * *$ \\
\hline $\mathrm{ET}^{*}$ & 0.155 & $0.462 *$ & $0.660 * *$ \\
\hline $\mathrm{SET}^{*}$ & 0.087 & $0.380 *$ & $0.524 * *$ \\
\hline \multicolumn{4}{|c}{$* * \mathrm{p}<0.01, \quad *: \mathrm{p}<0.05, \quad+: \mathrm{p}<0.1$}
\end{tabular}

場合, 居住者は着衣や代謝を調節することで好みの体感温度を得て いると考えられる。従って，環境条件を統制するために着衣や代謝

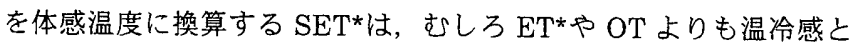
の相関が低くなることがあり得ると推測される。以上より, 本研究 で SET*之温冷感の相関が低かった原因は, 居住者の温熱感覚の個 人差が大きかったためであると考察できるのではないだろうか。

今回の調査では SET*と温冷感との相関は低かったが，一般的に はより多くの温熱要素を取り入れるほど温熱指標の評価精度が高く なることが期待される2て。そこで本研究では回帰分析の説明変数に, OT, ET*を用いた。そして説明変数ごとに重み付け線形回帰分析を 用いて回帰式を算出し，中立温度を検討する。

回㱕分析には $0.5^{\circ} \mathrm{C}$ 単位で切り上げた $\mathrm{OT}, \mathrm{ET}$ *に対応する温冷感 申告值の平均值を目的変数として用い, プロットした平均温冷感の サンプル数に応じた重み付け線形回帰分析を行った。

採暖なし時の温冷感を目的変数, 説明変数を $\mathrm{OT}, \mathrm{ET}$ *として分 析を行った結果, ET*を説明变数とした場合にのみ，温冷感申告 $=4$ となる温度はかろうじて内挿となり，以下の回帰式から中立温度を 求めることができた。

$\mathrm{TSV}=0.12 \mathrm{ET}^{*}+2.81 \quad[\mathrm{TSV}:$ 温冷感申告値 $] \cdots(2)$

回帰式は統計的に有意であり $\left(\mathrm{p}<0.0001, R^{2}=0.489\right)$ ，中立温度は $9.9^{\circ} \mathrm{C}\left(\mathrm{ET}^{*}\right)$ となった(図 6)。O OT では温冷感申告=4 となる温度は外 捙となり信頼性が低いため, 有効な中立温度は求めることはできな シった。

採暖あり時においても同様の方法で中立温度を予測しようとした $\therefore$ 温冷感申告 $=4$ となる温度は外挿となったので, 有効な中立温度 文求少ることはできなかったといえる。

\section{2.2 中立温度 (着衣量で居住者を分類した場合)}




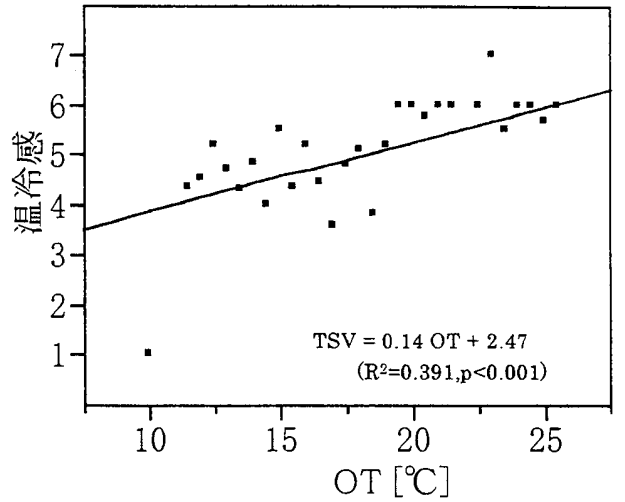

図 7 平均温冷感申告値とOTの関倸(厚着居住者)

表 7 間接的許容と熱的快適感の関係

\begin{tabular}{|c|c|c|c|c|}
\hline & & \multicolumn{2}{|c|}{ 熱的快薁感 } & \\
\hline & & 快適側 & 不快側 & 合計 \\
\hline \multirow{2}{*}{\multicolumn{2}{|c|}{$\frac{1}{2}$ 非許容 }} & $5(83.3 \%)$ & $1(16.7 \%)$ & 6 \\
\hline & & $4(80 \%)$ & $1(20 \%)$ & 5 \\
\hline \multirow{3}{*}{ 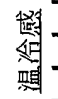 } & \multirow{3}{*}{ 許容 } & $24(80 \%)$ & $6(20 \%)$ & 30 \\
\hline & & $49(98 \%)$ & $1(2 \%)$ & 50 \\
\hline & & $84(95.5 \%)$ & $4(4.5 \%)$ & 88 \\
\hline \multirow{2}{*}{\multicolumn{2}{|c|}{$\frac{6}{7}$ 非許容 }} & $210(98.1 \%)$ & $4(1.9 \%)$ & 214 \\
\hline & & $3(100 \%)$ & $0(0 \%)$ & 3 \\
\hline & 合計 & 379 & 17 & 396 \\
\hline
\end{tabular}

温度 $\left(\mathrm{Ta}, \mathrm{Tg}, \mathrm{OT}, \mathrm{ET}^{*}, \mathrm{SET}^{*}\right)$ と温冷感の相関を調べた結果(表 6), 薄着の居住者の申告と温度との相関はほとんどなかった。薄着 の居住者には低温でも温冷感を「どちらでもない」などと申告する 傾向があったため，相関が低くなっている。この原因としては「薄 着の居住者は寒さに強い」，あるいは「温冷感が適切に申告されてい ない」などが考えられるが，本調査の結果のみでは明言できない。

厚着および中程度の居住者では, 正の相関（ $\mathrm{r}=0.380 \sim 0.752 ） か ゙$ 観 察された。そこで, 相関係数が大きく, 複数の温熱要素を加味して いる Tg，OT，ET*を用いた。そして先の方法と同様に重み付け線 形回帰分析により，厚着および中程度の居住者の中立温度を求めた。

厚着の居住者について分析を行った結果, 温冷感申告=4 となる温 度はかろうじて内挿となり，以下の回帰式から中立温度を求めるこ とができた。

$$
\begin{array}{llll}
\mathrm{TSV}=0.13 \mathrm{Tg}+2.70 & (\mathrm{p}<0.001, & \left.\mathrm{R}^{2}=0.338\right) & \cdots \\
\mathrm{TSV}=0.14 \mathrm{OT}+2.47 & (\mathrm{p}<0.001, & \left.\mathrm{R}^{2}=0.391\right) & \cdots(4) \\
\mathrm{TSV}=0.14 \mathrm{ET}^{*}+2.45 & (\mathrm{p}<0.001, & \left.\mathrm{R}^{2}=0.403\right) & \cdots \cdot(5)
\end{array}
$$

回帰式は統計的に有意であり, 中立温度は $9.9^{\circ} \mathrm{C}(\mathrm{Tg}), 10.9^{\circ} \mathrm{C}(\mathrm{OT})$, $10.9^{\circ} \mathrm{C}\left(\mathrm{ET}^{*}\right)$ となった(図 7)。 $\mathrm{SET}^{*}$ では温冷感申告=4 となる温度は 外挿となり，有効な中立温度を求めることはできなかった。

中程度の居住者においても同様の方法で中立温度を予測しようと したが, 温冷感申告=4 となる温度は外挿となり, 有効な中立温度は 求めることはできなかった。

以下で各国の既往研究と比較する。Fato, et al. ${ }^{28)}$ は南イタリアに

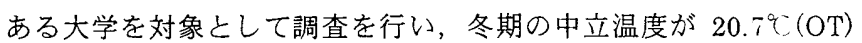
と報告している。Oseland ${ }^{29)}$ が英国の住宅で行った調查では，冬期 の中立温度は $17.0^{\circ} \mathrm{C}(\mathrm{OT})$ であった。リジャルら 300のネパールの住宅 を対象とした調査では, 冬期の中立温度は冷帯で $13.4^{\circ} \mathrm{C}(\mathrm{Tg})$-゙あっ た。居住者の温熱感覚に関する研究では, 室温に対する期待惑や環

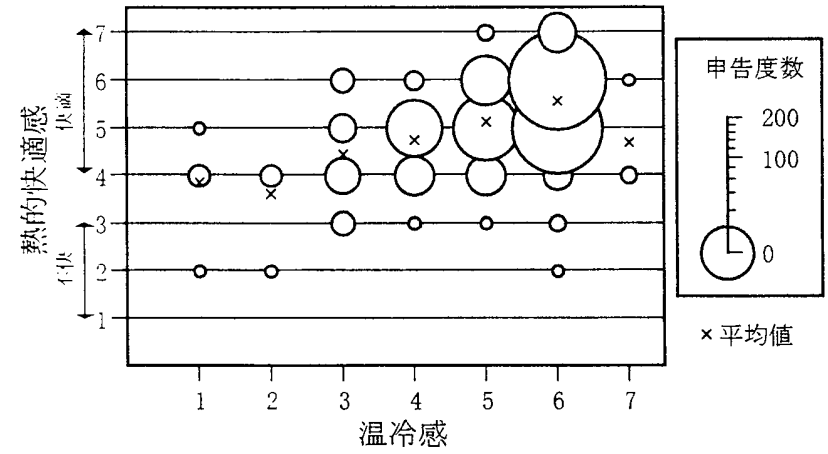

\begin{tabular}{|c|c|c|c|}
\hline & \multicolumn{2}{|c|}{ 熱的快適感 } & \\
\hline 幽 & 快適側 & 不快側 & 合計 \\
\hline 满 許容側 & $363(96.3 \%)$ & $14(3.7 \%)$ & 377 \\
\hline 佂 非許容側 & $4(33.3 \%)$ & $8(66.7 \%)$ & 12 \\
\hline 合計 & $367(94.3 \%)$ & $22(5.7 \%)$ & 389 \\
\hline
\end{tabular}

図 8 温冷感と熱的快適感の関係

表 8 直接的許容之熱的快適感の関係

境調節行動の影響も指摘されており31)，本研究では採暖の有無と着 衣量の観点から考察を行った。しかし本調查の中立温度は既往研究 よりもかなり低温の值であり，採暖や着衣量などの環境調節行動の 影響だけでは説明できない程低温の值であったと言える。しかし， 今回求められた值は回帰線の端部に近いため誤差も大きく，信頼性 が低いと思われ，今後も検討が必要である。

\section{3 許容範囲}

ASHRAE Standard4)では，熱的許容範囲を「不満足者率が $20 \%$ 以下となるような空間を実現する温度範囲を定めたもの」と定義し ている。本研究では，この定義を用いて熱的許容範囲を算出する。

熱的許容範囲の算出方法には，間接的許容(Indirect Acceptable ) と直接的許容(Direct Acceptable)の 2 種類の方法がある。間接的許 容は 7 段階の温冷感尺度の中央 3 段階(やや涼しい〜やや暖かい)を, 一方, 直接的許容は 6 段階の熱的許容度尺度の許容側(やや〜非常に 許容できる)を許容申告とする方法である。

表 7 に間接的許容と熱的快適感のクロス集計を示す。熱的快適感 は「とても不快(1)」〜「やや不快(3)」を不快側，「どちらでもない (4)」〜「とても快適(6)」を快適側とした。間接的許容の定義では暑 い側の不快領域である「暑い」「暖かい」の申告時にも，ほぼ全申告 が熱的に「快適」と回答している。すなわち間接的許容の定義を満 たさないため, 本研究の分析には不適当である。

本調査では温冷感申告として ASHRAE の 7 段階尺度の日本語訳 を用いた。しかし，英米語と日本語における意味の不一致等を理由 に,「涼しい」一「寒い」と「暖かい」一「暑い」との一次元的配置 については疑問視されている 32)33)。また，「暖かい」は比較的中庸 な温度感覚とともに「快適さ」や「安らぎ」の感情をも含む34こと が示されており，本研究でも「暖かい」で熱的快適感がもっとも快 適な側にあった。温冷感と熱的快適感の関係を図 8 に示す。横軸は 温冷感尺度, 縦軸は熱的快適感尺度, 円の半径は申告数を表してい る。全体的に右上がりの分布であり，温冷感が「暖かい」のときに 快適感の平均値が最も高かった。この尺度には前述のような問題点 もあるな゙，既往研究と比較することを重視して ASHRAE の 7 段階 
尺度の日本語訳を用いた。

次に表 8 に，直接的許容と熱的快適感のクロス集計を示す。熱的 許容度で非許容側の場合, $66 \%$ 以上が熱的快適感では不快側のき告 となっており，間接的許容よりも妥当な結果であるが，それでき全 申告に対して非許容側 $3 \%(\mathrm{~N}=12)$, 不快側 $5.7 \%(\mathrm{~N}=22)$ と申告数が ともに少ないため, 許容範囲は算出できなかった。以下に算出手順 を示す。

許容範囲を算出するため, $\mathrm{ET}^{*}$, OT $0.5^{\circ} \mathrm{C}$ 単位で切り上げ, そ の温度ごとに熱的許容度申告を非許容側 $(1 \sim 3)$ と許容側 $(4 \sim 6)$ の 2 種類にまとめた。熱的許容範囲の算出には許容度の不快側を分析に 用い, 温度ごとの全申告に対する非許容申告の割合である非許容率 を目的変数とした。説明変数を $\mathrm{ET}^{*}$, OT として, プロットした非 許容率のサンプル数に応じた 2 次の重み付け重回帰分析を行った。 そして非許容率が $20 \%$ 以下となる温度範囲を許容範囲として求め ようと試みたが, 採暖あり時, 採暖なし時ともに許容側の申告が多 く, 非許容率が常に $20 \%$ 未満であったために許容範囲を求めること ができなかった。

\section{4 許容率と居住者の価値観}

許容率の算出は, 熱的許容度の許容側申告が全申告に占める割合 を求める。熱環境を許容側に申告した割合は, 全申告で $92.9 \%$, 採 暖あり時の申告では $95.8 \%$ ，採暖なし時の申告では $90.2 \% て ゙ あ り ，$ ほとんどの居住者が今回調査した熱環境を「許容できる」と申告し ていた。今回調查した住宅の熱環境は, ASHRAE Standard4)に示さ れた快適域からはかなり逸脱していたにも関わらず，訴容率が $90 \%$ を超えていたことは注目に值する。

我が国で居住者が低温の環境を許容していることについては，い くつか報告がある。長谷川ら ${ }^{35}$ )は東北地方の住宅の実態調査から， 『廊下が寒いのは当然である』という意識を居住者は持っていると 述べている。佐藤豊ら ${ }^{36)}$ は栃木県の戸建住宅の実態調查から, 低温 の室内環境にありながらも居住者の不満や改善意欲はそれほど強く ないことを明らかにした。佐藤勝泰ら 3 円德島県・兵庫県では夏の 冷房対応が重要視され, 暖房に対する費用は特別なものとして認識 されていること, まず衣類の調整によって寒さに対応していること を示した。

また, 松原ら 38)39) は京都市内の居住者の対応・適応行動に関する 階層構造のモデル化を行い，たとえ「不快な」環境であっても居住 者の価值観・好みによっては「満足」が得られるとしている。今回 調査を行った関西地域の居住者は低温な熱環境でも許容できると申 告していたが，これは節約意識や長年の経験から構成される寒さへ のイメージなど, 寒さを許容するなんらかの意識・価値観を持って いたためではないだろうか。今後, 居住者の意識・価值観と温熱感 覚を関連付けた研究を行う必要があると思われる。

\section{5.まとめ}

関西地域の住宅を対象として，室内の熱環境に関する冬期の害態 調査を行った。温熱環境と温熱感覚の調査結果を, 生活時間調査に 基づいて整理・分析した結果を以下にまとめる。

1）暖房・採暖行為を同時に行っていた比率は全申告の $38.1 \%$ ありり, 暖房行為のみの $33.6 \%$ 上回っていた。暖房のみでは寒さをしの
ぎ切れず、多くの居住者が補助的に採暖行為を行っていたと推測 される。

2) 中立温度は採暖なし時で $9.9^{\circ} \mathrm{C}\left(\mathrm{ET}^{*}\right)$, また, 厚着 $(0.81 \sim 1.11 \mathrm{clo})$ をしている居住者で $9.9^{\circ} \mathrm{C}(\mathrm{Tg}), 10.9^{\circ} \mathrm{C}(\mathrm{OT}), 10.9^{\circ} \mathrm{C}(\mathrm{ET} *)$ と, 海 外の報告よりもかなり低温の值が求められた。しかし，この値は 回帰線の端部近くで求められた值であるため, 誤差の影響が否め ない。また, 薄着, 中間の居住者および採暖あり時の中立温度を 求めることはできなかった。

3）熱的許容範囲の算出において, 温冷感から求める間接的許容は定 義が満たされなかったので用いなかった。一方，熱的許容度から 求わる直接的許容では非許容側の申告数が全申告に対して $3 \%$ と 著しく少なかったため, 熱的許容範囲は求められなかった。

4）測定期間中の室温は 45\%がビル衛生管理法 16)の基準(気温 $17^{\circ} \mathrm{C}$ 以上)を下回る低温な環境であったが, 許容率は $90 \%$ 超えてお

り，居住者の多くが低温の温熱環境を容認していた。

今回の調査では低温の室内環境を多くの居住者が許容していたが， 健康面から見れば過度な寒さは好ましくない。また，居住者が寒さ を許容し、「暖かい」と申告したのは採暖行為や着衣量の調節などの 嘼境調節行為による影響だけでなく，居住者が寒さを許容するなん らかの意識・洒值観を持っていることが影響した可能性がある。ゆ えに温熱感覚の測定法を検討して調査を行うとともに, 環境調節行 為だけでなく居住者の意識・価值観と温熱感覚を関連付けた研究す る必要がある。

\section{謝辞}

調査にご協力いただいた居住者の皆様に感謝いたします。なお， 本研究の一部に平成 18 年度文部科学省科学研究費補助金基盤研究 $\mathrm{B}$ (代表：松原斎樹 課題番号 18300242)の助成を受けた。

注

注 1）生活時間調查は日記法を中心に行い，面接法で補足をした40)。日記法 とは、被験者に 1 日の行動を所定の用紙に記入させる方式である。この方 式の欠点は, 誤りが生じやすいことや, 記入の細かさや丁寧さに個人差が 生じることである。そこで事前に入念な説明をした上で記入例を添付した。 また用紙回収の際には, 記入用紙をもとに面接を行った。特に朝・夕食前後 は複数の生活行動が生起，終了する為，注意深く確認した。

注 2）本研究ではこたつ(112やホットカーペットなどの採暖器具だけでなく， ひざかけによる一時的な着衣量の增加とカイロ ${ }^{15)}$, 暖房器具の採暖的使用 1...111が居住者の温熱感覚に及ほす影響も無視できないと考えた。そのため， カイロやひざ掛けの使用、暖房器具の採暖的使用も採暖行為として扱うこ 亡上し，主観申告時に採暖行為を行っているか否かを記入してもらうこと で採暖行為の有無を調查した。

注3)军者らは文献 14)で, 居住者が，本来ならば部屋全体の空気を暖め, 寒 さこのものを取り除くために用いる暖房機器を, 温風や放射が直達する向 き:二調節して採暖を行っていることに注目した。本報でも暖房器具の放射 そ:量虽を期待した使用法に注目し、「暖房器具の採暖的使用」とした。

\section{参考文献}

1）桼ニネルギー・省資源対策推進会議省厅連絡会議 : 夏季の省エネルギーに 二: $て, 2002$

2）白二ネルギー・省資源対策推進会議省庁連絡会議：冬季の省エネルギーに 二:て, 2002

3) ISO : ISO international standard7730, 1994

4) ASHRAE : ASHRAE Standard55-2004, 2004 
5) Busch, J. F. : Thermal Responses to the Thai Office Environment, ASHRAE Transactions, 96(1), 859.872, 1990

6) Humphreys, M. A., and Nicol, J. F. : Understanding the Adaptive Approach to Thermal Comfort, ASHRAE Transaction, 104, 991-1004, 1998

7) 中村泰人: オフィスと住宅の至適温度の差異に関する考察, 日本建築学会 大会学術講演梗概集, 903-904, 1995

8）澤島智明他：住宅の断熱性能による冬期居間の温熱環境と暖房の仕方の差 異一関西地域における住宅の温熱環境と居住者の住まい方に関する事例 研究 その 1 -, 日本建築学会計画系論文集, No. $565 ， 75-81 ， 2003 ， 3$

9）中谷岳史他：関西地域の住宅における熱的快適性に関する実態調查一夏期 の中立温度と許容範囲一，No．597，日本建築学会環境系論文集，2005， 11

10)梅宮典子・中村泰人：温熱環境評価研究にお打る温感申告調查法の变遷 海外の研究における Thermal Comfort の申告調查法, 日本建築学会計画 計論文集, No. $518,13 \cdot 20,1999,4$

11) 渡倦慎一他：炬鈥使用時に㧍ける人体の熱的快適性の检討とその温熱効果 の定量化, 日本建築学会計画系論文集, No. 497，47.52，1997，7

12) 渡透慎一他: 炬燵と電気カーペットの併用が人体に及ほす影響之温熱的効 果, 日本建築学会計画系論文集, No. $515 ， 63-68 ， 1999 ， 1$

13)絵内正道, 荒谷登 : 居住室の温熱環境の実態一その 2 寒さに応じた住い 方と設定室温について一, 日本建築学会論文報告集, No. 265，105·113， 1978, 3

14)松原斎樹, 澤島智明 : 京都市近辺地域における冬期住宅居間の熱睘境之居 住者の住まい方に関する事例研究一暖房機器使用の特徵之団らん時の起 居様式一, 日本建築学会計画系論文集, No. $488,75 \cdot 84,1996,10$

15) 大道等: 携带用カイロの温熱効果一保温防寒具の運動科学一, 体育の科学, 46(1)，44-52, 1996

16)建築物における衛生的環境の確保に関する法律, 昭和 45 年法律第 20 号

17)西安信 : 温熱睘境の評価空気調和・衛生工学会「快適な温熱環境のメ力 ニズム」, 55·59, 1997

18) Benton, C. C. et al : A field measurement system for the study of thermal comfort, ASHRAE Transaction, 96. 623.633, 1990

19)藏澄美仁他: 姿勢の違认と日本人青年女性の安静時代謝量, 日本生気像学 会傕誌，36(1)，21·29，1999

20)藏澄美仁他: 作用温度 $28^{\circ} \mathrm{C}$ における日本人青年の安静時代謝量に及ぼす 姿勢の影響, 日本生気象学会雑誌，37(1)，27-37，2000

21) 花田嘉代子他 : 男子用下着類の熱抵抗の計測に関する研究, 緎維製品消費 科学会誌, $24,363 \cdot 369,1983$

22) 花田嘉代子他 : 婦人用下着類の熱抵抗の計測に関する研究，緎維製品消費 科学会誌, $22,430 \cdot 437,1981$

23) 花田嘉代子他: 男女洋服の熱抵抗の測定, 大阪市立大学生活科学部紀要, $35,111 \cdot 121,1987$

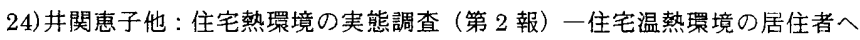
の影響について, 日本家政学会誌, 39(8)，879-884，1988

25)堀越哲美: PMV 之快適方程式の検討, 空気調和衛生工学, 60(10), 963-969, 1986

26)半澤久: 放射とその計測法 空気調和・衛生工学会「快適な温熱與境のメ カニズム」, 98·105, 1997

27)石井昭夫：温熱指標 架気調和・衛生工学会「快適な温熱㱬境のメカニズ 少, $67 \cdot 71,1997$

28) Fato, I. et al: Thermal Comfort in the Climatic Conditions of Southern Italy, ASHRAE Transaction, 110(2), 578-593, 2004

29) Oseland, N. A. : A comparison of the predicted and reported thermal sensation vote in homes during winter and summer, Energy and Buildings, 21, 45.54, 1994

30)リジャル・ホム・バハドゥル他: 住宅におけるネパール人の夏と冬に温熟感 賞，日本建築学会計画系論文報告集，No. 565，17-24，2003，3

31) Brager, G. and de Dear, R. : Thermal adaptation in the build environment : a literature review, Energy and Buildings, $27 . \leqslant 3 \cdot 96$, 1998

32) 堀越哲美: 熱睘境の快適性・温冷感に関する一考察, 日本建築学会大会学
術講演梗概集 D, 707-708, 1991

33) 大野秀夫, 久野覚: 温熱環境倸価用語の日本語と英語の対応について，日 本建築学会大会学術講演梗概集 D, 451·452, 1992

34) 室恵子他: 言語イメージの構造化に関する研究(3), 日本建築学会大会学術 講演梗概集 D, 477·478, 1992

35)長分川房雄他: 東北地方都市部の木造独立住宅における冬期の温熱眾境に 㽞する調查研究，日本建築学会論文報告集，No. 326，91·101，1983，4

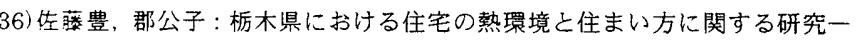
冬期の暖房室・非暖房室の熱睘境亡意識・住まい方一, 日本建築学会計画 系梳文集, No. $522,7 \cdot 14,1999,8$

37) 佐藤勝泰他 : 戸建住宅における冬期の住戸内外の温度環境亡居住者意識 . 生活行動一徳島県兵庫県, 北海道, カナダにおける生活実態調查の比較検 討一， 日本建築学会計画系論文集，No. 546，45-52，2001，8

38)松原斎樹，澤島智明：冬期の住宅居間の熱環境亡居住者の意識・住まい方 一その 3 居住者による猘境形成之評価のモテル化一, 日本建築学会大会学 術講演梗概集 D, 449·450，1992

39) Matsubara, N. et al. : Consciousness and behavior of the people and the indoor climate of houses in Japan, Proc. 1998 International Symposium of Human Biometeorology, 29·34, 1999

40) 矢野異和: 生活時間の社会学 社会の時間-個人の時間, 東京大学出版会, 1995 